J. Dairy Sci. 96:8094-8094

http://dx.doi.org/10.3168/jds.2013-96-12-8094

(C) American Dairy Science Association ${ }^{\circledR}, 2013$.

\title{
Erratum to "Hepatic and extrahepatic expression of serum amyloid A3 during lactation in dairy cows" (J. Dairy Sci. 96:6944-6954)
}

\section{B. Saremi, M. Mielenz, M. M. Rahman, A. Hosseini, C. Kopp, S. Dänicke, F. Ceciliani, and H. Sauerwein}

The digital object identifier (DOI) in the print version of this article was incorrect. The correct DOI is http://dx.doi.org/10.3168/jds.2013-6495.

The journal regrets the error.

\section{REFERENCES}

Saremi, B., M. Mielenz, M. M. Rahman, A. Hosseini, C. Kopp, S. Dänicke, F. Ceciliani, and H. Sauerwein. 2013. Hepatic and extrahepatic expression of serum amyloid A3 during lactation in dairy cows. J. Dairy Sci. 96(11):6944-6954. 